\title{
High rates of meticillin-resistant Staphylococcus aureus among asylum seekers and refugees admitted to Helsinki University Hospital, 2010 to 2017
}

Tuomas Aro ${ }^{1,2}$, Anu Kantele ${ }^{1,2,3}$

1. Department of Internal Medicine, Clinicum, Medical Faculty, University of Helsinki, Helsinki, Finland

2. Inflammation Center, University of Helsinki and Helsinki University Hospital, Helsinki, Finland

3. Karolinska Institutet, Stockholm, Sweden

Correspondence: Anu Kantele (anu.kantele@hus.fi)

Citation style for this article:

Aro Tuomas, Kantele Anu. High rates of meticillin-resistant Staphylococcus aureus among asylum seekers and refugees admitted to Helsinki University Hospital, 2010 to 2017. Euro Surveill. 2018;23(45):pii=1700797. https://doi.org/10.2807/1560-7917.ES.2018.23.45.1700797

Article submitted on 30 Nov 2017 / accepted on 28 Apr 2018 / published on 08 Nov 2018

Introduction: Antimicrobial resistance is increasing rapidly in countries with low hygiene levels and poorly controlled antimicrobial use. The spread of resistant bacteria poses a threat to healthcare worldwide. Refugees and migrants from high-prevalence countries may add to a rise in multidrug-resistant (MDR) bacteria in low-prevalence countries. However, respective data are scarce. Methods: We retrospectively collected microbiological and clinical data from asylum seekers and refugees treated at Helsinki University Hospital between January 2010 and August 2017. Results: Of 447 asylum seekers and refugees (Iraq: 46.5\%; Afghanistan: 10.3\%; Syria: 9.6\%, Somalia: $6.9 \%) ; 45.0 \%$ were colonised by MDR bacteria: $32.9 \%$ had extended-spectrum beta-lactamase-producing Enterobacteriaceae (ESBL-PE), 21.3\% meticillin-resistant Staphylococcus aureus (MRSA), $0.7 \%$ carbapenemase-producing Enterobacteriaceae (CPE), $0.4 \%$ multiresistant Pseudomonas aeruginosa (MRPA), 0.4\% multiresistant Acinetobacter baumannii (MRAB); no vancomycin-resistant Enterococcus (VRE) were found. Two or more MDR bacteria strains were recorded for $12.5 \%$ of patients. Multivariable analysis revealed geographical region and prior surgery outside Nordic countries as risk factors of MRSA colonisation. Young age ( $<6$ years old), short time from arrival to first sample, and prior hospitalisation outside Nordic countries were risk factors of ESBL-PE colonisation. Conclusion: We found MDR bacterial colonisation to be common among asylum seekers and refugees arriving from current conflict zones. In particular we found a high prevalence of MRSA. Refugees and migrants should, therefore, be included among risk populations requiring MDR screening and infection control measures at hospitals.

\section{Introduction}

Antimicrobial resistance (AMR), a major health problem worldwide, surges most rapidly in regions with low level of hygiene and poor control of antimicrobial use [1]. AMR spreads across the globe and its extent has been recognised by international bodies at the highest level: in 2016 AMR was addressed at a General Assembly session of the United Nations as the greatest and most urgent global health risk [2].

A major concern about AMR is its spread to healthcare settings in low-prevalence countries with severe consequences: treatment failures, increase in the number of serious infections, and dramatic cost implications [3]. To prevent the spread of AMR to hospitals, patients with particular risk of colonisation and infection with multidrug-resistant (MDR) bacteria should be identified and subjected to infection control measures at the admission stage. Numerous studies have identified international travel as a major risk factor for colonisation: approximately one third of visitors to high-prevalence regions acquire MDR bacteria during ordinary tourist travel [4-18]. Refugees and migrants who have lived for years in high-risk regions are presumed to have even higher levels of colonisation.

The European migrant crisis began in 2015 when over 1.2 million first-time asylum seekers (this group includes both refugees and migrants) applied for international protection in European Union countries $[19,20]$. Finland received 32,476 applications for asylum in 2015, an almost 10 -fold increase on previous years [21].

Like international travel, migration may contribute substantially to the spread of AMR [22-26]. Refugees and migrants mostly come from countries with considerably higher rates of MDR bacteria than Finland and, moreover, they may have journeyed through other 


\section{FIGURE 1}

Flowchart showing multidrug-resistant bacteria found in samples from asylum seekers and refugees admitted to Helsinki University Hospital, Finland, January 2010 to August $2017(\mathrm{n}=447)$

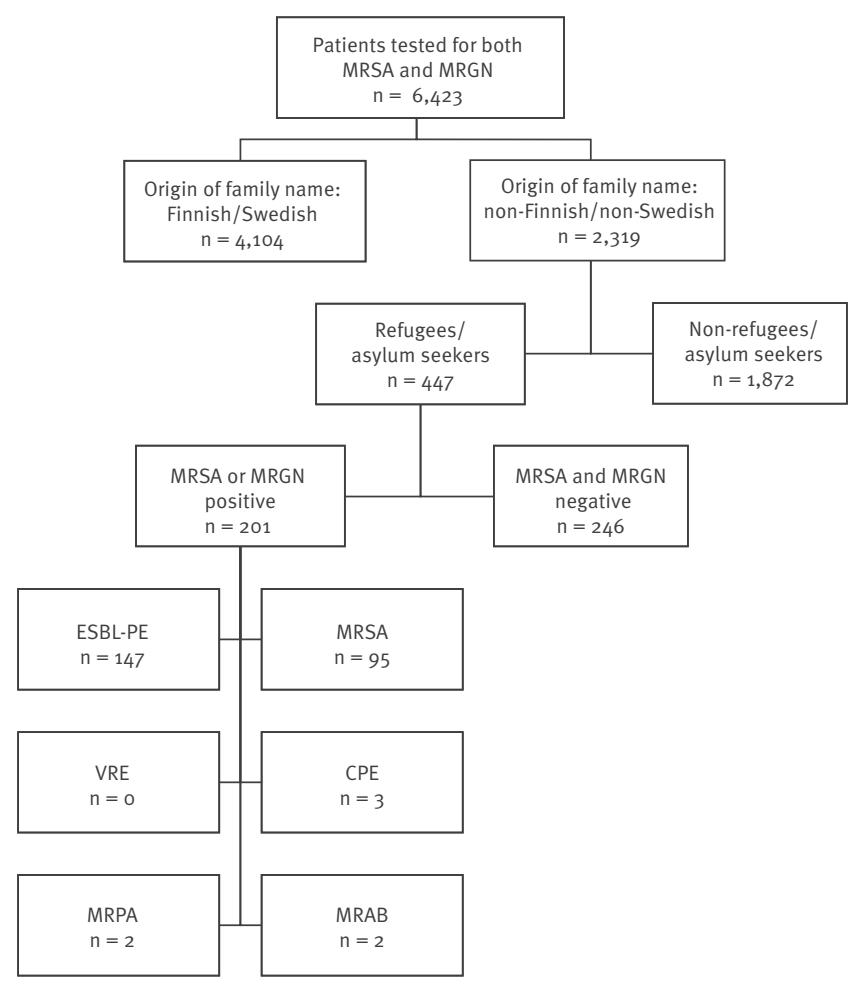

CPE: carbapenemase-producing Enterobacteriaceae; ESBL-PE: extended-spectrum beta-lactamase-producing Enterobacteriaceae; MRAB: multiresistant Acinetobacter baumannii; MRGN: multiresistant Gram-negative bacteria; MRPA: multiresistant Pseudomonas aeruginosa; MRSA: meticillin-resistant Staphylococcus aureus; VRE: vancomycin-resistant Enterococcus.

high-prevalence regions [1]. Accurate data on colonisation rates in this population are required to estimate transmission risk and to prepare infection control guidelines for hospitals. This retrospective study investigates the prevalence of various MDR bacteria among asylum seekers and refugees hospitalised in Finland, and seeks risk factors that can be used to identify those at highest risk of colonisation.

\section{Methods}

\section{Selection of participants}

Helsinki University Hospital ( $\mathrm{HUCH})$ provides secondary and tertiary care for the 1.6 million inhabitants of southern Finland. During the study period, from January 2010 to August 2017, our hospital's infection control guidelines stated that all asylum seekers and refugees admitted to hospitals should be screened at entry for meticillin-resistant Staphylococcus aureus (MRSA), vancomycin-resistant extended-spectrum Enterobacteriaceae Enterococcus (VRE), beta-lactamase-producing (ESBL-PE), carbapenemase-producing
(CPE), multiresistant Acinetobacter baumannii (MRAB) and multiresistant Pseudomonas aeruginosa (MRPA). The same screening guidelines were applied to patients who had been hospitalised outside the Nordic countries during the previous 12 months before admission to our hospital.

Using the HUCH infectious diseases database, SAl, we compiled a list of patients who had been sampled for both MRSA and multiresistant Gram-negative (MRGN) bacteria at hospital admission. Among these, we selected those with a non-Finnish/non-Swedish name and, after screening their patient charts, included only those who were asylum seekers or refugees (Figure 1). According to the Finnish Medical Research Act, review by an ethics committee is only required for research involving an intervention. The study protocol was approved by the research board of the Inflammation Center, Helsinki University Hospital, Finland.

\section{Collection of patient data}

For background information, we collected data from the patient records on sex, age, country of origin, date of arrival in Finland, prior hospitalisation and surgery (as recorded by the clinician), and determined Charlson Comorbidity Index (CCl) [27] for each subject. In addition, we collected data covering the results of bacterial cultures (blood, urine, stool), reason for admission, clinical diagnosis (ICD-10) [28] at discharge, MDR bacterial infections identified, and deaths. For further analysis, patients were grouped by geographical region according to their country of origin. Here we applied a classification (Figure 2) modified from United Nations geoscheme (Europe, North Africa and Middle East, sub-Saharan Africa, Asia, other) [29].

\section{Microbiological methods}

According to the hospital guidelines, swabs for screening patients for MDR bacteria are collected as follows: MRSA samples are taken each with a separate swab from the nostrils (one swab for both), pharynx and rectum or perineum. MRGN bacteria samples are collected as rectal swabs. In addition, swabs are taken from wound infections when applicable. The screening comprises two sets of samples, and where possible the samples are to be collected on consecutive days.

While some minor modifications to the routine laboratory practices took place during the study period, at the time of the last sampling, MDR bacterial analyses were carried out as follows: MRSA was screened by overnight enrichment on eMRSA broth (Copan Italia, Brescia, Italy) or selective in-house MRSA enrichment broth [30] followed by culture on CHROMagar MRSA (CHROMagar, Paris, France), and confirmed with $S$. aureus-specific nuclease and mecA gene qPCR [30]. VRE were screened by enrichment Enterococcosel Broth (BBL, Cockeysville, MD, United States of America (USA)) and followed by culture on CHROMagar VRE media. Positive findings were confirmed by in-house PCR as described by Suppola et al. [31]. 


\section{FIGURE 2}

Rate of multidrug-resistant bacteria among asylum seekers and refugees admitted to Helsinki University Hospital, by country of origin or geographical region, Finland, January 2010 to August 2017 ( $n=447)$

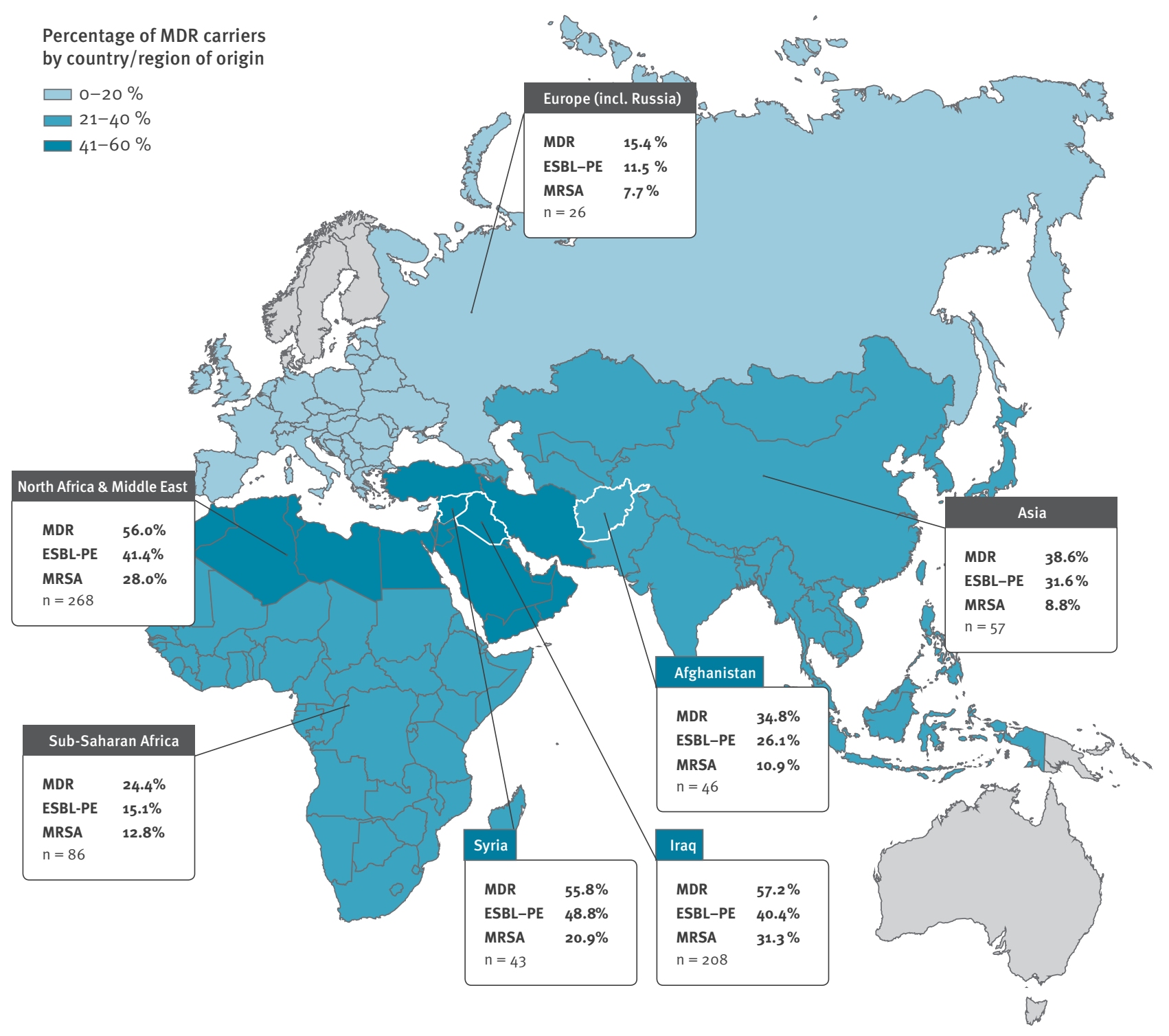

ESBL-PE: extended-spectrum beta-lactamase-producing Enterobacteriaceae; MDR: multidrug-resistant bacteria; MRSA: meticillin-resistant Staphylococcus aureus.

For nine patients, country of origin was not known. One patient was from Mexico (not shown in the map).

Patients' countries of origin in the various geographical regions:

Europe: Albania, Georgia, Greece, Kosovo*, Russia, Serbia, Ukraine;

North Africa and the Middle East: Iraq, Iran, Jordan, Kuwait, Lebanon, Morocco, Syria, Turkey, Yemen;

Sub-Saharan Africa: Burundi, Cameroon, Congo, Ethiopia, Eritrea, Gambia, Ghana, Kenya, Nigeria, Rwanda, Somalia, South Africa, Sudan, Uganda, Zambia;

Asia: Afghanistan, Azerbaijan, Kazakhstan, China, Kyrgyzstan, Myanmar, Nepal, Pakistan, Sri Lanka.

*This designation is without prejudice to positions on status, and is in line with United Nations Security Council Resolution $1244 / 99$ and the International Court of Justice Opinion on the Kosovo Declaration of Independence. 
Background characteristics of asylum seekers and refugees admitted to Helsinki University Hospital, by geographical region of origina, Finland, January 2010-August $2017(\mathrm{n}=447$ patients)

\begin{tabular}{|c|c|c|c|c|c|c|c|c|c|c|c|c|}
\hline \multirow[t]{2}{*}{ Patient attributes } & \multicolumn{2}{|c|}{$\begin{array}{l}\text { Europe } \\
n=26\end{array}$} & \multicolumn{2}{|c|}{$\begin{array}{c}\text { North Africa and } \\
\text { Middle East } \\
n=268\end{array}$} & \multicolumn{2}{|c|}{$\begin{array}{l}\text { Sub-Saharan } \\
\text { Africa } \\
n=86\end{array}$} & \multicolumn{2}{|c|}{$\begin{array}{l}\text { Asia } \\
n=57\end{array}$} & \multicolumn{2}{|c|}{$\begin{array}{c}\text { Other or } \\
\text { unknown } \\
n=10\end{array}$} & \multicolumn{2}{|c|}{$\begin{array}{c}\text { Total } \\
n=447\end{array}$} \\
\hline & $\mathrm{n}$ & $\%$ & $\mathrm{n}$ & $\%$ & $\mathrm{n}$ & $\%$ & $\mathrm{n}$ & $\%$ & $\mathrm{n}$ & $\%$ & $\mathrm{n}$ & $\%$ \\
\hline \multicolumn{13}{|l|}{ Sex } \\
\hline Male & 8 & 30.8 & 135 & 50.4 & 32 & 37.2 & 31 & 54.4 & 4 & 40.0 & 210 & 47.0 \\
\hline Female & 18 & 69.2 & 133 & 49.6 & 54 & 62.8 & 26 & 45.6 & 6 & 60.0 & 237 & 53.0 \\
\hline Median age (years) & \multicolumn{2}{|c|}{24} & \multicolumn{2}{|c|}{26} & \multicolumn{2}{|c|}{27} & \multicolumn{2}{|c|}{20} & \multicolumn{2}{|c|}{27} & \multicolumn{2}{|c|}{25} \\
\hline \multicolumn{13}{|l|}{ Age group (years) } \\
\hline $0-5$ & 3 & 11.5 & 36 & 13.4 & 7 & 8.1 & 6 & 10.5 & 2 & 20.0 & 54 & 12.1 \\
\hline $6-15$ & 3 & 11.5 & 32 & 11.9 & 3 & 3.5 & 15 & 26.3 & 0 & 0.0 & 53 & 11.9 \\
\hline $16-25$ & 9 & 34.6 & 64 & 23.9 & 31 & 36.0 & 14 & 24.6 & 3 & 30.0 & 121 & 27.1 \\
\hline $26-35$ & 8 & 30.8 & 98 & 36.6 & 30 & 34.9 & 12 & 21.1 & 4 & 40.0 & 152 & 34.0 \\
\hline$>35$ & 3 & 11.5 & 38 & 14.2 & 15 & 17.4 & 10 & 17.5 & 1 & 10.0 & 67 & 15.0 \\
\hline \multicolumn{13}{|l|}{ Charlson Comorbidity Index } \\
\hline o points & 24 & 92.3 & 251 & 93.7 & 80 & 93.0 & 52 & 91.2 & 10 & 100.0 & 417 & 93.3 \\
\hline 1 point & 0 & 0.0 & 3 & 1.1 & 1 & 1.2 & 2 & 3.5 & 0 & 0.0 & 6 & 1.3 \\
\hline 2-3 points & 2 & 7.7 & 11 & 4.1 & 4 & 4.7 & 3 & 5.3 & 0 & 0.0 & 20 & 4.5 \\
\hline $4-5$ points & 0 & 0.0 & 1 & 0.4 & 1 & 1.2 & 0 & 0.0 & 0 & 0.0 & 2 & 0.4 \\
\hline$>5$ points & 0 & 0.0 & 2 & 0.7 & 0 & 0.0 & 0 & 0.0 & 0 & 0.0 & 2 & 0.4 \\
\hline $\begin{array}{l}\text { Mean time from arrival to Finland } \\
\text { to first sample (days) }\end{array}$ & \multicolumn{2}{|c|}{78} & \multicolumn{2}{|c|}{127} & \multicolumn{2}{|c|}{100} & \multicolumn{2}{|c|}{119} & \multicolumn{2}{|c|}{363} & \multicolumn{2}{|c|}{119} \\
\hline \multicolumn{13}{|l|}{ Prior treatment history } \\
\hline Prior hospitalisation abroad & 5 & 19.2 & 54 & 20.1 & 15 & 17.4 & 6 & 10.5 & 0 & 0.0 & 80 & 17.9 \\
\hline Prior invasive procedure abroad & 2 & 7.7 & 34 & 12.7 & 9 & 10.5 & 4 & 7.0 & 0 & 0.0 & 49 & 11.0 \\
\hline
\end{tabular}

aPatients' countries of origin in the various geographical regions:

Europe: Albania, Georgia, Greece, Kosovo*, Russia, Serbia, Ukraine;

North Africa and Middle East: Iraq, Iran, Jordan, Kuwait, Lebanon, Morocco, Syria, Turkey, Yemen;

Sub-Saharan Africa: Burundi, Cameroon, Congo, Ethiopia, Eritrea, Gambia, Ghana, Kenya, Nigeria, Rwanda, Somalia, South Africa, Sudan, Uganda, Zambia;

Asia: Afghanistan, Azerbaijan, Kazakhstan, China, Kyrgyzstan, Myanmar, Nepal, Pakistan, Sri Lanka;

Other or unknown: Mexico, unknown.

*This designation is without prejudice to positions on status, and is in line with United Nations Security Council Resolution 1244/99 and the International Court of Justice Opinion on the Kosovo Declaration of Independence.

ESBL-PE and CPE were analysed by plating directly on CHROMagar ESBL and CHROMagar KPC or CHROMagar mSuperCARBA, respectively. ESBL-PE species identification was confirmed by MALDI-TOF (Vitek-MS, bioMérieux, Marcy l'Étoile, France) and resistance by standard EUCAST method [32]. CPE species were confirmed with in-house carbapenemase gene PCR.

MDR-P. aeruginosa and MDR-A. baumannii were screened from ESBL and KPC SuperCARBA plates. Cultures were tested by MALDI-TOF for species identification. Isolates resistant to meropenem for Acinetobacter, and both meropenem and ceftazidime for Pseudomonas, were analysed by PCR for carbapenemase genes as previously described [33].

\section{Statistics}

Data were entered on Microsoft Excel 2013 spreadsheets, and statistical analyses were conducted using
SPSS 24.0.0.0 software (IBM Corp., Armonk, NY, USA). In univariate analyses for categorical variables, chi-squared test, Fisher's exact test or binary logistic regression analysis was applied. For continuous variables, we used binary logistic regression. Chi-squared test and Fisher's exact test were two-sided. Variables for the multivariable model were selected using the $p$ value limit of 0.2 in the univariate model. Time between arrival and first sample was not known for all cases; missing values were taken into account by multiple imputations, assuming that data were missing at random. In the multivariable model, we used backward selection with Akaike information criteria (AIC) so as to choose the most informative explanatory variables for the final model. From several highly correlated variables, only one was included. 
Background characteristics of asylum seekers and refugees admitted to Helsinki University Hospital, by country of origin ${ }^{\mathrm{a}}$, Finland, January 2010-August 2017 ( $\mathrm{n}=447$ patients)

\begin{tabular}{|c|c|c|c|c|c|c|c|c|c|c|c|c|c|c|}
\hline \multirow[t]{2}{*}{ Patient attributes } & \multicolumn{2}{|c|}{$\begin{array}{l}\text { Iraq } \\
n=208\end{array}$} & \multicolumn{2}{|c|}{$\begin{array}{c}\text { Afghanistan } \\
n=46\end{array}$} & \multicolumn{2}{|c|}{$\begin{array}{l}\text { Syria } \\
n=43\end{array}$} & \multicolumn{2}{|c|}{$\begin{array}{l}\text { Somalia } \\
n=31\end{array}$} & \multicolumn{2}{|c|}{$\begin{array}{l}\text { Nigeria } \\
n=16\end{array}$} & \multicolumn{2}{|c|}{$\begin{array}{l}\text { Other or unknown } \\
\qquad n=103\end{array}$} & \multicolumn{2}{|c|}{$\begin{array}{c}\text { Total } \\
n=447\end{array}$} \\
\hline & $\mathrm{n}$ & $\%$ & $\mathrm{n}$ & $\%$ & $\mathrm{n}$ & $\%$ & $\mathrm{n}$ & $\%$ & $\mathrm{n}$ & $\%$ & $\mathrm{n}$ & $\%$ & $\mathrm{n}$ & $\%$ \\
\hline \multicolumn{15}{|l|}{ Sex } \\
\hline Male & 109 & 52.4 & 25 & $54 \cdot 3$ & 19 & 44.2 & 11 & $35 \cdot 5$ & 4 & 25.0 & 42 & 40.8 & 210 & 47.0 \\
\hline Female & 99 & 47.6 & 21 & $45 \cdot 7$ & 24 & 55.8 & 20 & 64.5 & 12 & 75.0 & 61 & 59.2 & 237 & 53.0 \\
\hline \multicolumn{15}{|l|}{ Age group (years) } \\
\hline $0-5$ & 27 & 13.0 & 4 & 8.7 & 5 & 11.6 & 1 & 3.2 & 1 & 6.3 & 16 & $15 \cdot 5$ & 54 & 12.1 \\
\hline $6-15$ & 20 & 9.6 & 12 & 26.1 & 9 & 20.9 & 2 & 6.5 & 0 & 0.0 & 10 & 9.7 & 53 & 11.9 \\
\hline $16-25$ & 54 & 26.0 & 13 & 28.3 & 9 & 20.9 & 17 & 54.8 & 4 & 25.0 & 24 & $23 \cdot 3$ & 121 & 27.1 \\
\hline $26-35$ & 76 & 36.5 & 10 & 21.7 & 15 & $34 \cdot 9$ & 8 & 25.8 & 10 & 62.5 & 33 & 32.0 & 152 & 34.0 \\
\hline \multicolumn{15}{|c|}{ Charlson Comorbidity Index } \\
\hline o points & 197 & $94 \cdot 7$ & 43 & 93.5 & 38 & 88.4 & 28 & 90.3 & 16 & 100.0 & 95 & 92.2 & 417 & 93.3 \\
\hline 1 point & 1 & 0.5 & 2 & $4 \cdot 3$ & 1 & 2.3 & 1 & 3.2 & 0 & 0.0 & 1 & 1.0 & 6 & 1.3 \\
\hline $2-3$ points & 7 & 3.4 & 1 & 2.2 & 4 & 9.3 & 2 & 6.5 & 0 & 0.0 & 6 & 5.8 & 20 & 4.5 \\
\hline $4-5$ points & 1 & 0.5 & 0 & 0.0 & 0 & 0.0 & 0 & 0.0 & 0 & 0.0 & 1 & 1.0 & 2 & 0.4 \\
\hline$>5$ points & 2 & 1.0 & 0 & 0.0 & 0 & 0.0 & 0 & 0.0 & 0 & 0.0 & 0 & 0.0 & 2 & 0.4 \\
\hline
\end{tabular}

aThe data are only presented for the five most common countries (in total, the study population originated in 41 different countries).

\section{Results}

\section{Subject characteristics}

According to the $\mathrm{HUCH}$ infectious diseases database SAI, 6,423 patients were screened for both MRSA and MRGN bacteria at admission between 1 January 2010 and 23 August 2017. A total of 2,319 patients with a non-Finnish/non-Swedish name were selected and their patient records screened (Figure 1). The final study population included 447 patients with refugee or asylum seeker status stated in their patient records. The increase in the number of refugees and asylum seekers admitted during the study period was evident: the vast majority $(86.8 \%)$ were hospitalised after the beginning of 2015. As shown by the demographic data presented in Tables 1 and 2, their median age was 25 years, and $53.0 \%$ were female. The patients had 41 different countries of origin, the majority in Iraq (46.5\%), Afghanistan $(10.3 \%)$, Syria (9.6\%), and Somalia (6.9\%). Most of the subjects (93.3\%) were healthy, with a CCl-score of 0 . Prior hospitalisation outside the Nordic countries was recorded for $17.9 \%$, an invasive procedure for $11.0 \%$, and treatment in an intensive care unit abroad for $4.0 \%$ of the patients. The median time from arrival in Finland to first MDR bacterial sampling was 59 days. The date of arrival in Finland was available for 283/447 patients (63.3\%).

\section{Cause of hospitalisation}

An infectious disease was the primary diagnosis for $83 / 447$ patients $(18.6 \%)$, most commonly confined to the respiratory $(21.7 \% ; 18 / 83)$ or urogenital tract
(13.3\%; $11 / 83)$, or presented as dermatological infection $(16.9 \% ; 14 / 83)$ or acute gastroenteritis $(7.2 \% ; 6 / 83)$. The majority of patients ( $81.4 \%$ ) had a non-infectious disease and nearly one third $(29.8 \% ; 133 / 447)$ of the admissions were associated with pregnancy.

\section{Findings of multidrug-resistant bacteria}

Almost half of the patients $(45.0 \% ; 201 / 447)$ were colonised by MDR bacteria: $32.9 \%$ had ESBL-PE, $21.3 \%$ MRSA, $0.7 \%$ CPE, $0.4 \%$ MRPA and $0.4 \%$ MRAB (Table $3)$. No cases with VRE were recorded. Two or more MDR strains were found in $12.5 \%$. The proportion of MDR bacterial carriers was found greatest among the patients from Iraq and Syria (57.2\% and $55.8 \%$ respectively), followed by Afghanistan (34.8\%) and Somalia $(25.8 \%)$ (Table 4). Analysis by geographical region (Table 3) showed the highest MDR bacterial colonisation rates for patients from North Africa and the Middle East (56.0\%). Patients from Asia and sub-Saharan Africa had MDR bacterial carriage rates of $38.6 \%$ and $24.4 \%$, respectively, while the result for those from Europe was $15.4 \%$ (Figure 2).

\section{Infections with multidrug-resistant bacteria}

Ten of the MDR bacterial carriers $(5.0 \% ; 10 / 201)$ had a clinical MDR bacterial infection verified by culture, with wound infections and urinary tract infections (UTI) as the most common manifestations. In six cases $(60.0 \%$; 6/10) the agent was identified as ESBL-PE, and in four (40.0\%; 4/10) as MRSA; $4.1 \%(6 / 147)$ of the ESBL-PE and $4.2 \%(4 / 95)$ of the MRSA carriers presented with a clinical infection. Among patients with a clinical 
The number of carriers of multidrug-resistant bacteria among asylum seekers and refugees admitted to Helsinki University Hospital, by geographical region of origina, Finland, January 2010-August 2017 ( $\mathrm{n}=447$ patients)

\begin{tabular}{|c|c|c|c|c|c|c|c|c|c|c|c|c|}
\hline \multirow[t]{2}{*}{ Patient attributes } & \multicolumn{2}{|c|}{$\begin{array}{l}\text { Europe } \\
n=26\end{array}$} & \multicolumn{2}{|c|}{$\begin{array}{l}\text { North Africa and } \\
\text { Middle-East } \\
n=268\end{array}$} & \multicolumn{2}{|c|}{$\begin{array}{l}\text { Sub-Saharan } \\
\text { Africa } \\
\text { n }=86\end{array}$} & \multicolumn{2}{|c|}{$\begin{array}{l}\text { Asia } \\
\mathrm{n}=57\end{array}$} & \multicolumn{2}{|c|}{$\begin{array}{l}\text { Other or unknown } \\
\qquad n=10\end{array}$} & \multicolumn{2}{|c|}{$\begin{array}{c}\text { Total } \\
\mathrm{n}=447^{\mathrm{b}}\end{array}$} \\
\hline & $n$ & $\%$ & $n$ & $\%$ & $\mathrm{n}$ & $\%$ & $\mathrm{n}$ & $\%$ & $\mathrm{n}$ & $\%$ & $\mathrm{n}$ & $\%$ \\
\hline Any MDR bacteria & 4 & 15.4 & 150 & 56.0 & 21 & 24.4 & 22 & 38.6 & 4 & 40.0 & 201 & 45.0 \\
\hline MRSA & 2 & 7.7 & 75 & 28.0 & 11 & 12.8 & 5 & 8.8 & 2 & 20.0 & 95 & 21.3 \\
\hline ESBL-PE & 3 & 11.5 & 111 & 41.4 & 13 & 15.1 & 18 & 31.6 & 2 & 20.0 & 147 & 32.9 \\
\hline VRE & 0 & 0.0 & 0 & 0.0 & 0 & 0.0 & 0 & 0.0 & 0 & 0.0 & 0 & 0.0 \\
\hline MRAB & 0 & 0.0 & 1 & 0.4 & 1 & 1.2 & 0 & 0.0 & 0 & 0.0 & 2 & 0.4 \\
\hline MRPA & 1 & 3.8 & 1 & 0.4 & 0 & 0.0 & o & 0.0 & 0 & 0.0 & 2 & 0.4 \\
\hline CPE & 0 & 0.0 & 3 & 1.1 & 0 & 0.0 & o & 0.0 & 0 & 0.0 & 3 & 0.7 \\
\hline $\begin{array}{l}\text { Multiple MDR bacteria } \\
\geq 2 \text { classes or strains of MDR } \\
\text { bacteria }\end{array}$ & 2 & 7.7 & 48 & 17.9 & 5 & 5.8 & 1 & 1.8 & 0 & 0.0 & 56 & 12.5 \\
\hline Clinical infection with MDR bacteria & 0 & 0.0 & 8 & 3.0 & 1 & 1.2 & 1 & 1.8 & 0 & 0.0 & 10 & 2.2 \\
\hline $\begin{array}{l}\text { Proportion of MDR bacteria carriers } \\
\text { with clinical MDR bacterial infection } \\
\text { (\%) }\end{array}$ & & b & & & & & & & & & & 0 \\
\hline
\end{tabular}

CPE: Carbapenemase-producing Enterobacteriaceae; ESBL-PE: extended-spectrum beta-lactamase-producing Enterobacteriaceae; MDR: multidrug-resistant; MRAB: multiresistant Acinetobacter baumannii; MRPA: multiresistant Pseudomonas aeruginosa; MRSA: meticillinresistant Staphylococcus aureus; VRE: Vancomycin-resistant Enterococcus.

aPatients' countries of origin in the various geographical regions:

Europe: Albania, Georgia, Greece, Kosovo*, Russia, Serbia, Ukraine;

North Africa and Middle East: Iraq, Iran, Jordan, Kuwait, Lebanon, Morocco, Syria, Turkey, Yemen;

Sub-Saharan Africa: Burundi, Cameroon, Congo, Ethiopia, Eritrea, Gambia, Ghana, Kenya, Nigeria, Rwanda, Somalia, South Africa, Sudan, Uganda, Zambia;

Asia: Afghanistan, Azerbaijan, Kazakhstan, China, Kyrgyzstan, Myanmar, Nepal, Pakistan, Sri Lanka

Other or unknown: Mexico, unknown.

${ }^{b}$ Some patients had two or more different ESBL-PE, CPE or MRSA strains.

*This designation is without prejudice to positions on status, and is in line with United Nations Security Council Resolution $1244 / 99$ and the International Court of Justice Opinion on the Kosovo Declaration of Independence.

infection as primary diagnosis, $10.8 \%$ (9/83) had an MDR bacterial infection.

UTIs were caused by ESBL E. coli (one patient) or ESBL Klebsiella pneumoniae (one patient). As for wound infections, MRSA was cultured in four cases (one with osteomyelitis) and ESBL Enterobacter cloacae in one. One patient with a wound infection had ESBL Proteus mirabilis detected both in bacterial culture of wound tissue and blood. Furthermore, there was one patient with a finding of ESBL Shigella, and in one case ESBL $E$. coli was cultured from perianal abscess. No deaths were directly attributed to infections with MDR bacteria.

\section{Meticillin-resistant Staphylococcus aureus findings}

The frequency of MRSA findings was 21.3\% (95/447) (Table 3). The highest rates were seen among patients coming from Iraq (31.3\%; 65/208) and Syria (20.9\%; 9/43), followed by those from Somalia $(12.9 ; 4 / 31)$ and Afghanistan (10.9\%; 5/46) (Table 4). The most common Staphylococcal protein A (spa)-types of MRSA isolates were t304 (24.4\%), t386 (11.5\%), t223 (10.3\%), to44 (6.4\%), and t127 (6.4\%). Spa-types seemed to differ by country of origin (Table 4 ). The median times from arrival in Finland to first sample among MRSAcarriers and non-carriers were 97 and 51 days, respectively (Table 5); the difference was not statistically significant.

\section{Multiresistant Gram-negative bacteria findings} CPE strains (K. pneumoniae, E. coli, Acinetobacter baumannii, and Proteus mirabilis) were found in the samples of two patients from Iraq and one from Syria; both Iraqis had multiple CPE strains. MRPA was recorded for two patients, one Russian, the other Iraqi. One refugee from Cameroon and one from Iraq were screened positive for MRAB.

One third of the patients $(32.9 \% ; 147 / 447)$ were colonised by ESBL-PE, with the highest frequency seen among patients of North African and Middle Eastern origin $(41.4 \% ; 111 / 268)$. Nearly half of the Syrians (48.8\%; 21/43) were ESBL-PE carriers, while Iraqis and Afghans had carriage rates of $40.4 \%(84 / 208)$ and $26.1 \%(12 / 46)$, respectively (Table 4 ). Most ESBL-PE strains were $E$. coli (90.2\%), followed by K. pneumoniae (6.1\%), Proteus 
The number of carriers of multidrug-resistant bacteria among asylum seekers and refugees admitted to Helsinki University Hospital, as presented by five most common countries of origin ${ }^{\mathrm{a}}$, Finland, January 2010-August 2017 ( $\mathrm{n}=447$ patients)

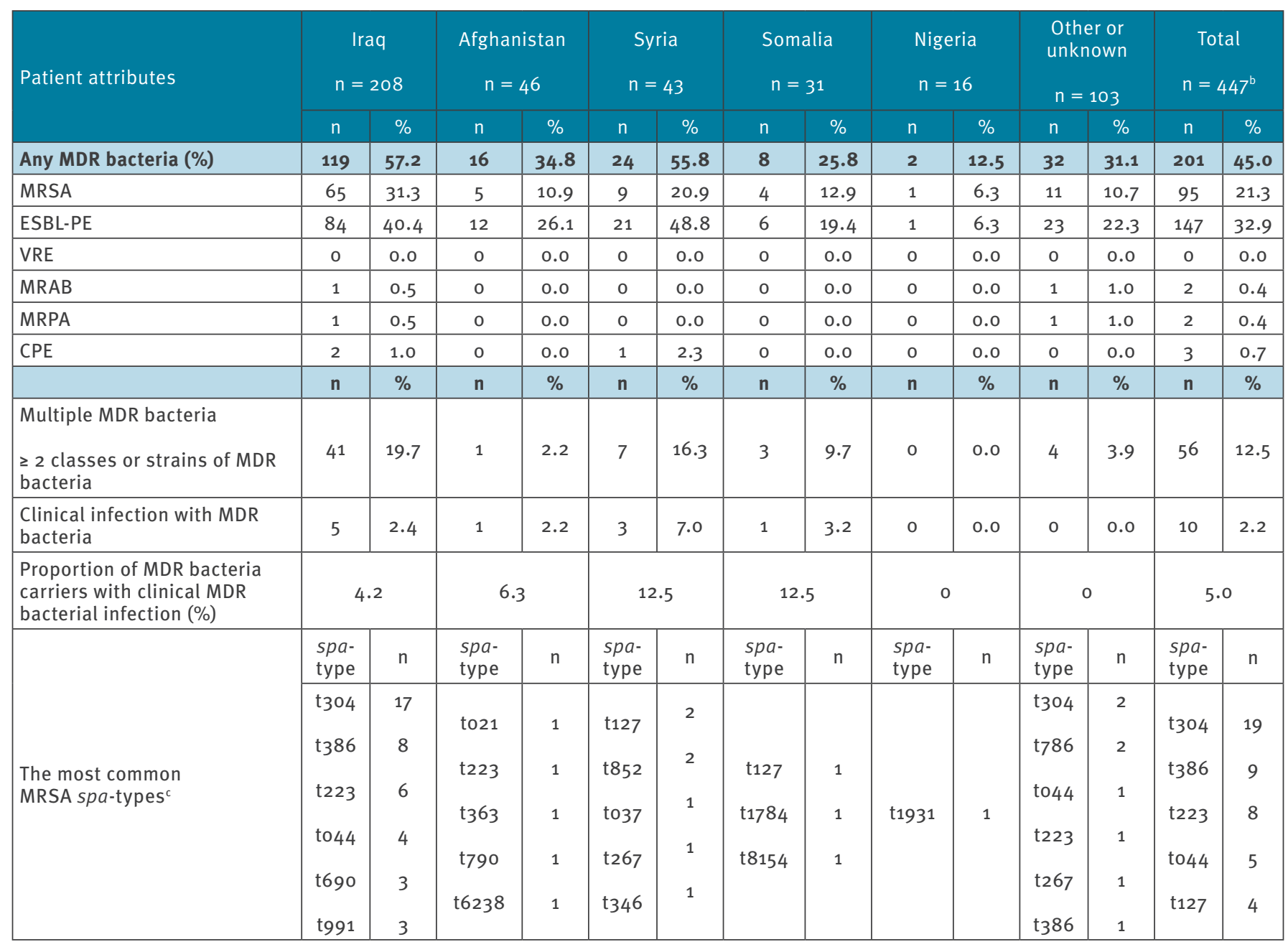

CPE: carbapenemase-producing Enterobacteriaceae; ESBL-PE: extended-spectrum beta-lactamase-producing Enterobacteriaceae; MDR: multidrug-resistant; MRAB: Multiresistant Acinetobacter baumannii; MRPA: multiresistant Pseudomonas aeruginosa; MRSA: meticillinresistant Staphylococcus aureus; spa: staphylococcal protein A; VRE: vancomycin-resistant Enterococcus.

an total, the study population originated in 41 different countries.

bSome patients had two or more different ESBL-PE, CPE or MRSA strains.

'The spa-types of some MRSA samples were not available.

mirabilis (2.4\%) and Enterobacter cloacae (0.6\%). The median time from arrival in Finland to first sample was significantly shorter among ESBL-PE-carriers (38 days) than non-carriers (83 days) (Table 5).

\section{Extended-spectrum beta-lactamase-producing} Enterobacteriaceae with co-resistance to other antimicrobials

Co-resistance to other antibiotics proved common among the ESBL strains: two thirds (62.2\%; 102/164) of the ESBL-PE isolates showed decreased sensitivity to co-trimoxazole and more than one third were coresistant to levofloxacin $(40.2 \% ; 66 / 164)$ or tobramycin (34.1\%; 56/164). Resistance to levofloxacin was associated with co-resistance to tobramycin (OR 6.0, $95 \%$ confidence intervals $(\mathrm{Cl})$ : 3.0-12.2) but not co-trimoxazole
(OR 1.7, 95\% Cl: 0.9-3.3) in univariate analysis. No statistical differences were seen in co-resistance between the various geographical regions.

\section{Risk factor analysis of meticillin-}

resistant Staphylococcus aureus colonisation In multivariable analysis, geographical region and prior invasive procedure outside the Nordic countries were found to be independent risk factors of MRSA colonisation. No other risk factors were identified. (Table 6)

\section{Risk factor analysis of extended-spectrum} beta-lactamase-producing Enterobacteriaceae colonisation

We identified by univariate analysis the following factors as predisposing to ESBL-PE: young age, 
TABLE 5

The results of univariate and multivariable risk factor analyses of extended-spectrum beta-lactamase-producing Enterobacteriaceae carriage among asylum seekers and refugees admitted to Helsinki University Hospital, Finland, January 2010-August 2017 ( $\mathrm{n}=447)$

\begin{tabular}{|c|c|c|c|c|c|c|c|c|c|}
\hline \multirow[t]{2}{*}{ Risk factor } & \multirow{2}{*}{$\begin{array}{c}\text { Patients } \\
\frac{(n=447)}{n}\end{array}$} & \multicolumn{2}{|c|}{$\begin{array}{l}\text { ESBL-PE } \\
\text { carriers } \\
(n=147)\end{array}$} & \multicolumn{2}{|c|}{$\begin{array}{c}\text { Non-carriers } \\
(\mathrm{n}=300)\end{array}$} & \multirow[t]{2}{*}{$\begin{array}{c}\text { OR }(95 \% \mathrm{Cl}) \\
\text { in univariate } \\
\text { analysis }\end{array}$} & \multirow[t]{2}{*}{$\begin{array}{c}\mathrm{p} \text { value in } \\
\text { univariate } \\
\text { analysis }\end{array}$} & \multirow[t]{2}{*}{$\begin{array}{c}\text { AOR }(95 \% \mathrm{Cl}) \\
\text { in multivariable } \\
\text { analysis }^{\mathrm{a}}\end{array}$} & \multirow[t]{2}{*}{$\begin{array}{l}\mathrm{p} \text { value in } \\
\text { multivariable } \\
\text { analysis }\end{array}$} \\
\hline & & $n$ & $\%$ & $n$ & $\%$ & & & & \\
\hline \multicolumn{10}{|l|}{ Sex } \\
\hline Female & 237 & 68 & 28.7 & 169 & 71.3 & 1.0 & NA & NA & NA \\
\hline Male & 210 & 79 & 37.6 & 131 & 62.4 & $1.5(1.0-2.2)$ & 0.045 & NA & NA \\
\hline \multicolumn{7}{|l|}{ Age group (years) } & $<0.001$ & & \\
\hline $0-5$ & 54 & 30 & 55.6 & 24 & 44.4 & 1.0 & NA & 1.0 & NA \\
\hline $6-15$ & 53 & 16 & 30.2 & 37 & 69.8 & $0.3(0.2-0.8)^{b}$ & 0.009 & $0.2(0.1-0.5)^{b}$ & 0.001 \\
\hline $16-25$ & 121 & 30 & 24.8 & 91 & 75.2 & $0.3(0.1-0.5)^{b}$ & $<0.001$ & $0.3(0.2-0.7)^{b}$ & 0.003 \\
\hline $26-35$ & 152 & 44 & 28.9 & 108 & 71.1 & $0.3(0.2-0.6)^{b}$ & $<0.001$ & $0.4(0.2-0.8)^{b}$ & 0.010 \\
\hline$>35$ & 67 & 27 & 40.3 & 40 & 59.7 & $0.5(0.3-1.1)^{b}$ & 0.096 & $0.5(0.2-1.2)^{b}$ & 0.123 \\
\hline \multicolumn{7}{|l|}{ Geographical regionc } & $<0.001$ & & \\
\hline Europe & 26 & 3 & 11.5 & 23 & 88.5 & 1.0 & NA & 1.0 & NA \\
\hline $\begin{array}{l}\text { North Africa and } \\
\text { Middle East }\end{array}$ & 268 & 111 & 41.4 & 157 & 58.6 & $5.4(1.6-18.5)^{d}$ & 0.007 & $7.7(2.1-28.1)^{\mathrm{d}}$ & 0.002 \\
\hline Sub-Saharan Africa & 86 & 13 & 15.1 & 73 & 84.9 & $1.4(0.4-5.2)^{\mathrm{d}}$ & 0.649 & $1.4(0.4-5.9)^{\mathrm{d}}$ & 0.617 \\
\hline Asia & 57 & 18 & 31.6 & 39 & 68.4 & $3.5(0.9-13.3)^{d}$ & 0.062 & $5.9(1.4-24.1)^{\mathrm{d}}$ & 0.014 \\
\hline Other or unknown & 10 & 2 & 20.0 & 8 & 80.0 & $1.9(0.3-13.6)^{d}$ & 0.516 & $7.0(0.8-64.9)^{d}$ & 0.086 \\
\hline \multicolumn{10}{|c|}{ Prior hospitalisation abroad } \\
\hline No or not specified & 367 & 100 & 27.2 & 267 & 72.8 & 1.0 & NA & 1.0 & NA \\
\hline Yes & 80 & 47 & 58.8 & 33 & 41.3 & $3.8(2.3-6.3)$ & $<0.001$ & $4.1(2.3-7.4)$ & $<0.001$ \\
\hline \multicolumn{10}{|c|}{ Prior invasive procedure abroad } \\
\hline No or not specified & 398 & 118 & 29.6 & 280 & 70.4 & 1.0 & NA & NA & NA \\
\hline Yes & 49 & 29 & 59.2 & 20 & 40.8 & $3.4(1.9-6.3)$ & $<0.001$ & NA & NA \\
\hline \multicolumn{10}{|l|}{ Prior ICU care abroad } \\
\hline No or not specified & 429 & 134 & 31.2 & 295 & 68.8 & 1.0 & NA & NA & NA \\
\hline Yes & 18 & 13 & 72.2 & 5 & 27.8 & $5.7(2.0-16.4)$ & 0.001 & NA & NA \\
\hline $\begin{array}{l}\text { Time from arrival to } \\
\text { first sample (days, } \\
\text { median)e }\end{array}$ & 59 & \multicolumn{2}{|c|}{38} & \multicolumn{2}{|c|}{83} & $0.91(0.85-0.96)^{e}$ & 0.002 & $0.91(0.86-0.97)$ & 0.002 \\
\hline \multicolumn{7}{|c|}{ Charlson Comorbidity Index (points) } & 0.063 & & \\
\hline 0 & 417 & 133 & 31.9 & 284 & 68.1 & 1.0 & NA & NA & NA \\
\hline 1 & 6 & 1 & 16.7 & 5 & 83.3 & $0.4(0.05-3.7)^{f}$ & 0.439 & NA & NA \\
\hline $2-3$ & 20 & 13 & 65.0 & 7 & 35.0 & $4.0(1.5-10.2)^{f}$ & 0.004 & NA & NA \\
\hline $4-5$ & 2 & 0 & 0 & 2 & 100 & NA & NA & NA & NA \\
\hline$>5$ & 2 & 0 & 0 & 2 & 100 & NA & NA & NA & NA \\
\hline
\end{tabular}

AOR: adjusted odds ratio; CI: confidence interval; ESBL-PE: extended-spectrum beta-lactamase-producing Enterobacteriaceae; ICU: intensive care unit; NA: not applicable; OR: odds ratio; SD: standard deviation.

aWhen selecting the variables for the multivariable model with binary logistic regression, the Akaike information criteria (AIC) was used. Time between arrival and first sample was not known for all cases; missing values were taken into account by multiple imputations, assuming that data were missing at random.

${ }^{\mathrm{b}}$ Compared with the youngest age group.

'Patients' countries of origin in the various geographical regions:

Europe: Albania, Georgia, Greece, Kosovo*, Russia, Serbia, Ukraine;

North Africa and Middle East: Iraq, Iran, Jordan, Kuwait, Lebanon, Morocco, Syria, Turkey, Yemen;

Sub-Saharan Africa: Burundi, Cameroon, Congo, Ethiopia, Eritrea, Gambia, Ghana, Kenya, Nigeria, Rwanda, Somalia, South Africa, Sudan, Uganda, Zambia;

Asia: Afghanistan, Azerbaijan, Kazakhstan, China, Kyrgyzstan, Myanmar, Nepal, Pakistan, Sri Lanka.

${ }^{\mathrm{d} C o m p a r e d ~ w i t h ~ E u r o p e . ~}$

${ }^{e} n=283$; only in 283/447 cases arrival date to Finland was known. Analysed as a continuous variable, OR and adjusted OR given per 30 days.

${ }^{\mathrm{f} C o m p a r e d}$ with those with o points.

*This designation is without prejudice to positions on status, and is in line with United Nations Security Council Resolution $1244 / 99$ and the International Court of Justice Opinion on the Kosovo Declaration of Independence. 
geographical region, short time from arrival to first sample, prior hospitalisation, prior invasive procedure abroad, and prior ICU care (Table 5). The final multivariable analysis revealed geographical region of origin, age under 6 years, short time from arrival to first sample and prior hospitalisation abroad as independent risk factors for colonisation. As for the geographical region of origin, the ESBL-PE colonisation rates were significantly higher among North African, Middle Eastern and Asian patients than Europeans (Table 5). Of factors with $p$ value under 0.2 in univariate analysis, male sex, prior invasive procedure abroad, prior ICU care, and general health ( $\mathrm{CCl}$ score) were eliminated from the final model on the basis of the AIC.

\section{Discussion}

Data remain scarce on AMR carriage rates in refugees and migrants [24]. The present investigation reveals MDR bacterial colonisation and a high prevalence of MRSA of $21.3 \%$ among asylum seekers and refugees seeking healthcare at a tertiary hospital in Finland.

Although focusing on AMR, we also collected general data on refugees and migrants and causes of their hospitalisation. Although $79 \%$ of the asylum seekers who have arrived in Finland since 2015 have been male [34], in our data no clear sex difference in hospital admission was seen; the discrepancy can probably be explained by our high number of obstetric hospitalisations. Overall, our patients were in good general health; the greatest number of visits (29.8\%) were reported for the specialty of obstetrics, while infectious diseases accounted for fewer than one in five cases. Respiratory, skin, and urinary tract infections were the most common causes among infectious diseases. Obviously, these are also common causes of hospitalisation among the host population. The proportion of minors corresponded to that of refugee and migrant minors arriving in Finland (24.9\%) [35].

\section{Level of colonisation by any multidrug- resistant bacteria}

Nearly half of the patients were colonised by MDR bacteria, a finding consistent with recent research focusing on refugees admitted to hospitals [36-38]. In Germany, Tenenbaum et al. reported an MDR bacterial carriage rate of $33.8 \%(110 / 325)$ in a paediatric population in 2015 to 2016 [36], and Reinheimer et al. rates of $52.1 \%$ (61/117) in 2015 to 2016 and 66.4\% (95/143) in 2015 in two studies with both adult and paediatric patients $[37,38]$. The various countries of birth may account for the differences: in the previous studies, most of the patients were Syrians and Afghans, whereas in ours, nearly half were Iraqis. The high overall rate of MDR bacterial colonisation among refugees and asylum seekers justifies infection control measures, according with rates of $55.2 \%$ demonstrated in another group routinely subjected to isolation at hospitals in lowprevalence countries, namely travellers with a recent history of hospitalisation in the (sub)tropics [39].
As we expected, the clinical ESBL-PE infections generally proved to be UTIs; MDR bacterial wound infections were mostly attributed to MRSA. Data on the frequency of MDR bacterial carriers developing an infection with the MDR bacterial strain are scarce. Among returning travellers treated on an infectious and tropical diseases ward in France from 2012 to 2013, Epelboin et al. [40] found that one in five MRGN bacterial carriers identified $(21.7 \%, 5 / 23)$ also had a clinical MRGN bacterial infection, albeit in a very small sample. The difference between our rates and those of Epelboin et al. (5.0\% vs $21.7 \%$, respectively) can probably be explained by two points related to the selection of population. Firstly, our data included a high proportion of healthy obstetric patients with no MDR bacterial infections. Secondly, in the investigation by Epelboin all patients had a clinical infection, while ours looked retrospectively at all patients, admitted for any reason, who at admission to a tertiary hospital had been sampled for both MRSA and MRGN bacteria, and whom we could identify as asylum seekers and refugees from their patient records. Indeed, of our patients who had infectious disease as primary diagnosis, $10.8 \%$ had an MDR bacterial infection. In our previous study looking at 1,122 Finnish patients hospitalised abroad for diverse reasons, we found that $11.4 \%$ (38/333) of those colonised with MDR bacteria had an infection with the same MDR bacteria [39].

\section{Colonisation by MRSA}

A major finding emerging from our investigation was that MRSA carriage in asylum seekers and refugees is considerably more common than expected. This proportion significantly exceeds those of German studies that have reported rates from $5.6 \%$ to $9.8 \%(8 / 143$ and $32 / 325$ ) [37,41], and rates of $15.7 \%$ recorded at Swiss asylum seeker reception centres [42]. MRSA carriage also proved more prevalent in the study population than among regular travellers hospitalised in the (sub)tropics: Khawaja et al. reported 6.6\% (25/377) for 2010-2013 [39], Kaspar et al. 2\% for 2012-2013 [43], Nemeth et al. $1.2 \%$ for 2009-2011 [44], and Birgand et al. $3.8 \%$ for $2012-2013$ [45]. This relevant and valuable finding should be taken heed of when drawing up infection control guidelines for hospital admission of refugees and asylum seekers.

An analysis of spa-types revealed that the MRSA strains differ from those most commonly seen in clinical samples in Finland (too8, t172, to67) [46]. Clear differences were found between those with different countries of origin, suggesting that the strains had not originated in Finland but that refugees had been MRSA carriers on arrival. The median time from arrival in Finland to first sample was almost twice as long among MRSA carriers than among non-carriers. A tendency was seen for MRSA rates to grow as their stay in Finland lengthened, but the difference was not statistically significant (Table 6). 
TABLE 6

The results of univariate and multivariable risk factor analyses of meticillin-resistant Staphylococcus aureus colonisation among asylum seekers and refugees admitted to Helsinki University Hospital, Finland, January 2010 to August 2017 $(\mathrm{n}=447)$

\begin{tabular}{|c|c|c|c|c|c|c|c|c|c|}
\hline \multirow[t]{2}{*}{ Risk Factor } & \multirow{2}{*}{$\begin{array}{c}\text { Patients } \\
(n=447) \\
n\end{array}$} & \multicolumn{2}{|c|}{$\begin{array}{c}\text { MRSA } \\
\text { carriers } \\
(n=95)\end{array}$} & \multicolumn{2}{|c|}{$\begin{array}{l}\text { Non-carriers } \\
(\mathrm{n}=352)\end{array}$} & \multirow[t]{2}{*}{$\begin{array}{c}\text { OR }(95 \% \mathrm{Cl}) \\
\text { in univariate } \\
\text { analysis }\end{array}$} & \multirow[t]{2}{*}{$\begin{array}{l}p \text { value in } \\
\text { univariate } \\
\text { analysis }\end{array}$} & \multirow[t]{2}{*}{$\begin{array}{c}\text { AOR }(95 \% \mathrm{Cl}) \\
\text { in multivariable } \\
\text { analysis }^{\mathrm{a}}\end{array}$} & \multirow[t]{2}{*}{$\begin{array}{c}p \text { value in } \\
\text { multivariable } \\
\text { analysis }\end{array}$} \\
\hline & & $\mathrm{n}$ & $\%$ & $\mathrm{n}$ & $\%$ & & & & \\
\hline \multicolumn{10}{|l|}{ Sex } \\
\hline Female & 237 & 47 & 19.8 & 190 & 80.2 & 1.0 & NA & NA & NA \\
\hline Male & 210 & 48 & 22.9 & 162 & 77.1 & $1.2(0.8-1.9)$ & 0.435 & NA & NA \\
\hline \multicolumn{7}{|l|}{ Age group (years) } & 0.806 & & \\
\hline $0-5$ & 54 & 13 & 24.1 & 41 & 75.9 & 1.0 & NA & NA & NA \\
\hline $6-15$ & 53 & 11 & 20.8 & 42 & 79.2 & $0.8(0.3-2.1)^{b}$ & 0.681 & NA & NA \\
\hline $16-25$ & 121 & 22 & 18.2 & 99 & 81.8 & $0.7(0.3-2.1)^{b}$ & 0.369 & NA & $N A$ \\
\hline $26-35$ & 152 & 36 & 23.7 & 116 & 76.3 & $1.0(0.5-2.0)^{b}$ & 0.954 & NA & NA \\
\hline$>35$ & 67 & 13 & 19.4 & 54 & 80.6 & $0.8(0.3-1.8)^{b}$ & 0.535 & NA & NA \\
\hline \multicolumn{7}{|l|}{ Geographical region $^{c}$} & 0.002 & & \\
\hline Europe & 26 & 2 & 7.7 & 24 & 92.3 & 1.0 & NA & 1.0 & NA \\
\hline $\begin{array}{l}\text { North Africa and Middle } \\
\text { East }\end{array}$ & 268 & 75 & 27.6 & 197 & 72.4 & $4.7(1.1-20.2)^{d}$ & 0.040 & $4.5(1.0-19.7)^{d}$ & 0.044 \\
\hline Sub-Saharan Africa & 86 & 11 & 13.4 & 71 & 86.6 & $1.8(0.4-8.5)^{\mathrm{d}}$ & 0.482 & $1.7(0.4-8.4)^{d}$ & 0.500 \\
\hline Asia & 57 & 5 & 8.8 & 52 & 91.2 & $1.2(0.2-6.4)^{d}$ & 0.870 & $1.2(0.2-6.4)^{d}$ & 0.864 \\
\hline Other or unknown & 10 & 2 & 20.0 & 8 & 80.0 & $3.0(0.4-24.9)^{\mathrm{d}}$ & 0.309 & $3.2(0.4-26.9)^{d}$ & 0.279 \\
\hline \multicolumn{10}{|c|}{ Prior hospitalisation abroad } \\
\hline No or not specified & 367 & 72 & 19.6 & 295 & 80.4 & 1.0 & NA & NA & NA \\
\hline Yes & 80 & 23 & 28.8 & 57 & 71.3 & $1.7(1.0-2.9)$ & 0.072 & NA & NA \\
\hline \multicolumn{10}{|c|}{ Prior invasive procedure abroad } \\
\hline No or not specified & 398 & 78 & 19.6 & 320 & 80.4 & 1.0 & NA & 1.0 & NA \\
\hline Yes & 49 & 17 & 34.7 & 32 & 65.3 & $2.2(1.2-4.1)$ & 0.017 & $2.0(1.1-3.9)$ & 0.033 \\
\hline \multicolumn{10}{|l|}{ Prior ICU care abroad } \\
\hline No or not specified & 429 & 89 & 20.7 & 340 & 79.3 & 1.0 & NA & NA & NA \\
\hline Yes & 18 & 6 & 33.3 & 12 & 66.7 & $1.9(0.7-5.2)$ & 0.208 & NA & NA \\
\hline $\begin{array}{l}\text { Time from arrival to first } \\
\text { sample (days, median) }\end{array}$ & 59 & & 97 & & & $1.05(0.99-1.10)^{e}$ & 0.079 & NA & NA \\
\hline \multicolumn{7}{|c|}{ Charlson comorbidity index (points) } & 0.626 & & \\
\hline 0 & 417 & 93 & 22.3 & 324 & 77.7 & 1.0 & NA & NA & NA \\
\hline 1 & 6 & 1 & 16.7 & 5 & 83.3 & $0.7(0.1-6.0)^{f}$ & 0.743 & NA & NA \\
\hline $2-3$ & 20 & 1 & 5.0 & 19 & 95.0 & $0.1(0.02-1.4)^{f}$ & 0.100 & NA & NA \\
\hline $4-5$ & 2 & 0 & 0 & 2 & 100 & NA & NA & NA & NA \\
\hline$>5$ & 2 & 0 & 0 & 2 & 100 & NA & NA & NA & NA \\
\hline
\end{tabular}

AOR: adjusted odds ratio; CI: confidence interval; ICU: intensive care unit; MRSA: meticillin-resistant Staphylococcus aureus; NA: not applicable; OR: odds ratio; SD: standard deviation.

${ }^{a}$ When selecting the variables for the multivariable model with binary logistic regression, the Akaike information criteria (AIC) was used. Time between arrival and first sample was not known for all cases; missing values were taken into account by multiple imputations, assuming that data were missing at random.

${ }^{b}$ Compared with the youngest age group.

'Patients' countries of origin in the various geographical regions:

Europe: Albania, Georgia, Greece, Kosovo*, Russia, Serbia, Ukraine;

North Africa and Middle East: Iraq, Iran, Jordan, Kuwait, Lebanon, Morocco, Syria, Turkey, Yemen;

Sub-Saharan Africa: Burundi, Cameroon, Congo, Ethiopia, Eritrea, Gambia, Ghana, Kenya, Nigeria, Rwanda, Somalia, South Africa, Sudan, Uganda, Zambia;

Asia: Afghanistan, Azerbaijan, Kazakhstan, China, Kyrgyzstan, Myanmar, Nepal, Pakistan, Sri Lanka.

${ }^{\mathrm{d} C o m p a r e d ~ w i t h ~ E u r o p e . ~}$

${ }^{e} n=283$, only in $283 / 447$ cases arrival date to Finland was known. Analysed as a continuous variable, OR and adjusted OR given per 30 days.

${ }^{\mathrm{f}}$ Compared with those with o points.

*This designation is without prejudice to positions on status, and is in line with United Nations Security Council Resolution $1244 / 99$ and the International Court of Justice Opinion on the Kosovo Declaration of Independence. 


\section{Colonisation by multiresistant bacteria}

The rising number of CPEs has aroused great concern in Europe [47]. CPE findings have been reported for $0-2.1 \%$ of refugee patients $[37,41,48]$. Likewise, our study found the CPE rates to be low. Of course, even at these levels, they exceed the background rate in Finland [49]; special attention is warranted, since they may rise further, running parallel to increasing AMR prevalence in the various countries of origin.

As for MRAB and MRPA colonisation, two cases of each were identified; none with VRE were found, a valuable piece of information for professionals planning infection control measures in hospitals.

ESBL-PE were the most commonly recorded MDR bacteria. Detected among one third of the refugees and migrants, the rates remained lower than in two studies by Reinheimer et al. [37,38] in Germany, reporting 52.1\% $(61 / 117)$ and $58.7 \%(84 / 143)$ prevalence, yet accorded with rates identified in samples from unaccompanied refugee minors in Frankfurt in 2015 (35.3\%, 42/119) [50]. The colonisation rates among refugees resembled those reported for regular travellers $(20-70 \%)[51,52]$, the figures probably reflecting country-related background colonisation rates. Traveller studies show significant differences depending on destination $[51,52]$; the highest numbers are seen among visitors to major risk regions such as the Indian subcontinent.

It appears, however, that the initial ESBL-PE rates of asylum seekers and refugees on arrival in Finland may actually have been higher than recorded here: those with longer time since arrival had a lower ESBL-PE carriage frequency than those sampled soon after immigration. Indeed, recent follow-up studies show that travellers' ESBL-PE carriage tends to be transient and detectable only for a few months after return $[15,53]$. While the acquisition rates reported in traveller studies are based on samples collected soon after travellers' return, in the present study the median time from arrival to sampling was approximately 8 weeks. Further research is needed into carriage duration among refugees and migrants or other people with a recent history of long-term exposure to MDR bacteria.

A substantial proportion of our ESBL-PE isolates proved co-resistant to levofloxacin, tobramycin or cotrimoxazole, which accords with the results of studies exploring colonisation among travellers $[4,9,11,12]$. Co-resistance to levofloxacin correlated with resistance to tobramycin but not co-trimoxazole. This finding may be related to a genetic linkage between the resistance mechanisms of the first two $[54,55]$.

\section{Risk factor analysis}

To identify potential risk factors of MRSA and ESBL-PE colonisation, we conducted univariate and multivariable analysis of the items derived from the patient records. To our knowledge, until now, risk factor analyses have not been included in refugee/migrant studies $[36-38,41,48,50]$.

As independent risk factors of MRSA colonisation, we recognised geographical region and prior invasive procedure outside the Nordic countries. The latter accords with previous studies showing prior healthcare contact to be a risk factor of MRSA colonisation at hospital admission $[56,57]$. In our research, the highest risk of MRSA colonisation was seen among patients from North Africa and Middle East, which is in line with an investigation by Stenhem et al. analysing imported MRSA cases in Sweden from 2000 to 2003 [58]. Some of the other risk factors of MRSA colonisation such as prior infections or antibiotic treatments, occupation (e.g. healthcare worker) or contact with livestock could not be covered, due to the retrospective nature of our study [57].

For ESBL-PE colonisation, the final multivariable analyses revealed as independent risk factors geographical region, young age ( 6 years old), short time from arrival to first sample, and prior hospitalisation outside the Nordic countries. Geographical region has been identified in virtually all traveller studies analysing ESBL-PE risk factors $[5,12-14,16,52]$. The highest risk has been linked with Asia and the Middle East [5-7,9-18], a finding that agrees with our results. Likewise, prior hospitalisation has been established as a risk factor for MDR bacterial carriage among travellers [59]. One previous result contradictory to ours showed a correlation between young age and lower rates of ESBL-PE colonisation [13]. Indeed, refugee children and travelling minors cannot be regarded as comparable: tourist children's exposure to food/drink contaminated with intestinal microbes is of shorter duration, and, moreover, trying to avoid diarrhoea, their parents probably select less risky food for them.

Traveller studies have also identified a number of other risk factors, such as occurrence of diarrhoea $[5,6,9,10,13-15]$ and use of antibiotics $[6,13,15-17]$. Unfortunately, these predisposing factors could not be included in our analyses since such data could not be consistently drawn from our patient records.

\section{Limitations}

Due to the retrospective design of our study, the data were limited to those available in patient records. Some relevant factors such as antibiotic use could not be analysed. Information concerning the itineraries of the refugees and asylum seekers was lacking, and dates of arrival in Finland were recorded for only $63.3 \%$ of the patients. The research was conducted in a tertiary hospital which is reflected in the selection of the patients. Females were over-represented in our study population (53.0\%), probably because of the large proportion of pregnancy-related hospital visits. After the beginning of 2015 only $21.2 \%$ of all asylum seekers arriving in Finland were female [6o]. 


\section{Conclusions}

Our study shows considerable carriage rates for MDR bacteria among refugees and asylum seekers admitted to a tertiary hospital in Finland. The data suggest that these patients should be considered a risk group that requires both screening of MDR bacteria and infection control measures at entry to hospitals in low-prevalence countries. In particular the refugee and migrant population's considerable MRSA colonisation rate warrants attention in healthcare settings.

\section{Note}

*This designation is without prejudice to positions on status, and is in line with United Nations Security Council Resolution 1244/99 and the International Court of Justice Opinion on the Kosovo Declaration of Independence.

\section{Acknowledgements}

Authors thank Jukka Ollgren (National Institute for Health and Welfare, Helsinki, Finland) for expert advice in statistical analyses, Sointu Mero for valuable comments on the description of microbiological methods, and Topi Kairenius for graphic design of Figure 2. This work was supported by the Finnish Governmental Subsidy for Health Science Research, the Sigrid Juselius Foundation, the Finnish Cultural Foundation, and the Scandinavian Society for Antimicrobial Chemotherapy Foundation. The funding sources had no involvement in study design, collection, analysis and interpretation of data, devising manuscript, and decision to submit the article for publication.

\section{Conflict of interest}

TA declares no conflicts of interest; AK has received honorary for lectures (Pfizer, MSD, Valneva, Immuron) and an investigator-initiated grant (Pfizer), and has on two occasions consulted an advisory board (Valneva), none of these relevant to the current manuscript.

\section{Authors' contributions}

Study concept and design AK; acquisition of data TA; analysis and interpretation of results TA, AK; drafting of manuscript TA, AK; statistical analysis TA; final approval of version published TA, AK.

\section{References}

1. World Health Organization (WHO). Antimicrobial resistance: global report on surveillance. Geneva: WHO; 2014. Available from: http://www.who.int/drugresistance/documents/ surveillancereport/en/

2. World Health Organization (WHO). At UN, global leaders commit to act on antimicrobial resistance. Geneva: WHO; 2016. Available from: http://www.who.int/mediacentre/news/ releases/2016/commitment-antimicrobial-resistance/en/

3. Schwaber MJ, Navon-Venezia S, Kaye KS, Ben-Ami R, Schwartz D, Carmeli Y. Clinical and economic impact of bacteremia with extended- spectrum-beta-lactamaseproducing Enterobacteriaceae. Antimicrob Agents Chemother. 2006;50(4):1257-62. https://doi.org/10.1128/AAC.50.4.12571262.2006 PMID: 16569837

4. Tham J, Odenholt I, Walder M, Brolund A, Ahl J, Melander E. Extended-spectrum beta-lactamase-producing Escherichia coli in patients with travellers' diarrhoea. Scand J Infect Dis. 2010;42(4):275-80.
5. Tängdén T, Cars O, Melhus A, Löwdin E. Foreign travel is a major risk factor for colonization with Escherichia coli producing CTX-M-type extended-spectrum beta-lactamases: a prospective study with Swedish volunteers. Antimicrob Agents Chemother. 2010;54(9):3564-8. https://doi.org/10.1128/ AAC.00220-10 PMID: 20547788

6. Kennedy K, Collignon P. Colonisation with Escherichia coli resistant to "critically important" antibiotics: a high risk for international travellers. Eur J Clin Microbiol Infect Dis. 2010;29(12):1501-6. https://doi.org/10.1007/s10096-0101031-y PMID: 20835879

7. Peirano G, Laupland KB, Gregson DB, Pitout JDD. Colonization of returning travelers with CTX-M-producing Escherichia coli. J Travel Med. 2011;18(5):299-303. https://doi.org/10.1111/ j.1708-8305.2011.00548.x PMID: 21896092

8. Weisenberg SA, Mediavilla JR, Chen L, Alexander EL, Rhee $\mathrm{KY}$, Kreiswirth BN, et al. Extended spectrum beta-lactamaseproducing Enterobacteriaceae in international travelers and non-travelers in New York City. Woodrow CJ, editor. 2012;7(9):e45141.

9. Ostholm-Balkhed A, Tärnberg M, Nilsson M, Nilsson LE, Hanberger H, Hällgren A. Travel-associated faecal colonization with ESBL-producing Enterobacteriaceae: incidence and risk factors. 2013 May 14;68(9):2144-53

10. Lausch KR, Fuursted K, Larsen CS, Storgaard M. Colonisation with multi-resistant Enterobacteriaceae in hospitalised Danish patients with a history of recent travel: a cross-sectional study. Travel Med Infect Dis. 2013;11(5):320-3. https://doi. org/10.1016/j.tmaid.2013.06.004 PMID: 23810306

11. Paltansing S, Vlot JA, Kraakman MEM, Mesman R, Bruijning ML, Bernards AT, et al. Extended-spectrum $\beta$-lactamaseproducing enterobacteriaceae among travelers from the Netherlands. Emerg Infect Dis. 2013;19(8):1206-13. https:// doi.org/10.3201/eid1908.130257 PMID: 23885972

12. Kuenzli E, Jaeger VK, Frei R, Neumayr A, DeCrom S, Haller S, et al. High colonization rates of extended-spectrum $\beta$-lactamase (ESBL)-producing Escherichia coli in Swiss travellers to South Asia- a prospective observational multicentre cohort study looking at epidemiology, microbiology and risk factors. BMC Infect Dis. 2014;14(1):528. https://doi.org/10.1186/1471-2334 14-528 PMID: 25270732

13. Kantele A, Lääveri T, Mero S, Vilkman K, Pakkanen SH, Ollgren J, et al. Antimicrobials increase travelers' risk of colonization by extended-spectrum betalactamase-producing Enterobacteriaceae. Clin Infect Dis. 2015;60(6):837-46. https://doi.org/10.1093/cid/ciu957 PMID: 25613287

14. Lübbert C, Straube L, Stein C, Makarewicz O, Schubert S, Mössner J, et al. Colonization with extended-spectrum beta-lactamase-producing and carbapenemase-producing Enterobacteriaceae in international travelers returning to Germany. Int J Med Microbiol. 2015;305(1):148-56. https://doi. org/10.1016/j.ijmm.2014.12.001 PMID: 25547265

15. Ruppé E, Armand-Lefèvre L, Estellat C, Consigny P-H, El Mniai A, Boussadia Y, et al. High Rate of Acquisition but Short Duration of Carriage of Multidrug-Resistant Enterobacteriaceae After Travel to the Tropics. Clin Infect Dis. 2015;61(4):593-600. https://doi.org/10.1093/cid/civ333 PMID: 25904368

16. Angelin $M$, Forsell J, Granlund $M$, Evengård $B$, Palmgren $H$, Johansson A. Risk factors for colonization with extendedspectrum beta-lactamase producing Enterobacteriaceae in healthcare students on clinical assignment abroad: A prospective study. Travel Med Infect Dis. 2015;13(3):223-9. https://doi.org/10.1016/j.tmaid.2015.04.007 PMID: 25982453

17. Reuland EA, Al Naiemi N, Kaiser AM, Heck M, Kluytmans JAJW, Savelkoul PHM, et al. Prevalence and risk factors for carriage of ESBL-producing Enterobacteriaceae in Amsterdam. J Antimicrob Chemother. 2016;71(4):1076-82. https://doi. org/10.1093/jac/dkv441 PMID: 26755493

18. Barreto Miranda I, Ignatius R, Pfüller R, Friedrich-Jänicke B, Steiner F, Paland M, et al. High carriage rate of ESBL-producing Enterobacteriaceae at presentation and follow-up among travellers with gastrointestinal complaints returning from India and Southeast Asia. J Travel Med. 2016;23(2):tav024. https:// doi.org/10.1093/jtm/tav024 PMID: 26858272

19. Eurostat. Record number of over 1.2 million first time asylum seekers registered in 2015. Luxembourg: Eurostat; 2016. Available from: http://ec.europa.eu/eurostat/ documents/2995521/7203832/3-04032016-AP-EN.pdf

20. The UN Refugee Agency (UNHCR). Global Trends: Forced Displacement in 2015. Geneva: UNHCR; 2016. Available from: http://www.unhcr.org/statistics/unhcrstats/576408cd7/unhcrglobal-trends-2015.html

21. Finnish Immigration Service. The Finnish Immigration Service's statistical summary 2015. Helsinki: Finnish Immigration Service; 2016. Available from: http://www.migri.fi/ download/65019_Tilastograafit_2015_EN final.pdf 
22. MacPherson DW, Gushulak BD, Baine WB, Bala S, Gubbins PO, Holtom P, et al. Population mobility, globalization, and antimicrobial drug resistance. Emerg Infect Dis. 2009;15(11):1727-32. PMID: 19891858

23. van der $\mathrm{Bij}$ AK, Pitout JDD. The role of international travel in the worldwide spread of multiresistant Enterobacteriaceae. J Antimicrob Chemother. 2012;67(9):2090-100. https://doi. org/10.1093/jac/dks214 PMID: 22678728

24. de Smalen AW, Ghorab H, Abd El Ghany M, Hill-Cawthorne GA. Refugees and antimicrobial resistance: A systematic review. Travel Med Infect Dis. 2017;15:23-8. https://doi.org/10.1016/j. tmaid.2016.12.001 PMID: 27919742

25. Maltezou HC. Antibiotic resistance and the refugee crisis in Europe - Preemptive action is indicated. Travel Med Infect Dis. 2016;14(2):69-70. https://doi.org/10.1016/j.tmaid.2016.03.009 PMID: 27044610

26. Nellums LB, Thompson H, Holmes A, Castro-Sánchez E, Otter JA, Norredam M, et al. Antimicrobial resistance among migrants in Europe: a systematic review and meta-analysis. Lancet Infect Dis. 2018;18(7):796-811. https://doi.org/10.1016/ S1473-3099(18)30219-6 PMID: 29779917

27. Charlson ME, Pompei P, Ales KL, MacKenzie CR. A new method of classifying prognostic comorbidity in longitudinal studies: development and validation. J Chronic Dis. 1987;40(5):373-83. https://doi.org/10.1016/0021-9681(87)90171-8 PMID: 3558716

28. World Health Organization (WHO). International statistical classification of diseases and related health problems. 10th Revision. Volume 2. Instruction manual. 2010 ed. Geneva: WHO; 2011. Available from: http://www.who.int/ classifications/icd/ICD10Volume2_en_2010.pdf

29. United Nations Statistics Division (UNSD). Standard country or area codes for statistical use (M49). New York: UNSD. [Accessed 6 Apr 2018]. Available from: https://unstats.un.org/ unsd/methodology/m49/

30. Pasanen T, Korkeila M, Mero S, Tarkka E, Piiparinen H, Vuopio-Varkila J, et al. A selective broth enrichment combined with real-time nuc-mecA-PCR in the exclusion of MRSA. APMIS. 2010;118(1):74-80. https://doi.org/10.1111/j.16000463.2009.02562.x PMID: 20041874

31. Suppola JP, Kolho E, Salmenlinna S, Tarkka E, Vuopio-Varkila J, Vaara M. vanA and vanB incorporate into an endemic ampicillin-resistant vancomycin-sensitive Enterococcus faecium strain: effect on interpretation of clonality. J Clin Microbiol. 1999;37(12):3934-9. PMID: 10565910

32. The European Committee on Antimicrobial Susceptibility Testing (EUCAST). Breakpoint tables for interpretation of MICs and zone diameters. Version 7.1. Växjö: EUCAST; 2017. Available from: http://www.eucast.org/ast_of_bacteria/ previous_versions_of_documents/

33. Pasanen T, Koskela S, Mero S, Tarkka E, Tissari P, Vaara M, et al. Rapid Molecular Characterization of Acinetobacter baumannii Clones with rep-PCR and Evaluation of Carbapenemase Genes by New Multiplex PCR in Hospital District of Helsinki and Uusimaa. Mokrousov I, editor. 2014 Jan 21;9(1):e85854-8. Available from: http://dx.plos.org/10.1371/ journal.pone.0085854

34. Finnish Immigration Service. Statistics - International protection. Helsinki: Finnish Immigration Service. [Accessed 22 Nov 2017]. Available from: http://statistics.migri. $\mathrm{fi} / \#$ decisions/23330?start $=540$

35. Finnish Immigration Service. Asylum applications 1/201512/2015. Helsinki: Finnish Immigration Service; 2017. Available from: http://statistics.migri.fi/\#applications/23330/49?start= 540 \&end $=551$

36. Tenenbaum T, Becker K-P, Lange B, Martin A, Schäfer P, Weichert S, et al. Prevalence of Multidrug-Resistant Organisms in Hospitalized Pediatric Refugees in an University Children's Hospital in Germany 2015-2016. Infect Control Hosp Epidemiol. 2016;37(11):1310-4. https://doi.org/10.1017/ice.2016.179 PMID: 27523304

37. Reinheimer C, Kempf VAJ, Göttig S, Hogardt M, Wichelhaus TA, O'Rourke F, et al. Multidrug-resistant organisms detected in refugee patients admitted to a University Hospital, Germany JuneDDecember 2015. Euro Surveill. 2016;21(2):30110-5. https://doi.org/10.2807/1560-7917.ES.2016.21.2.30110 PMID: 26794850

38. Reinheimer C, Kempf VAJ, Jozsa K, Wichelhaus TA, Hogardt M, O'Rourke F, et al. Prevalence of multidrug-resistant organisms in refugee patients, medical tourists and domestic patients admitted to a German university hospital. BMC Infect Dis. 2017;17(1):17. https://doi.org/10.1186/s12879-016-2105-y PMID: 28056820

39. Khawaja T, Kirveskari J, Johansson S, Väisänen J, Djupsjöbacka A, Nevalainen A, et al. Patients hospitalized abroad as importers of multiresistant bacteria-a cross-sectional study.
Clin Microbiol Infect. 2017;23(9):673.e1-8. https://doi. org/10.1016/j.cmi.2017.02.003 PMID: 28196696

40. Epelboin L, Robert J, Tsyrina-Kouyoumdjian E, Laouira S, Meyssonnier V, Caumes EMDR-GNB Travel Working Group. High Rate of Multidrug-Resistant Gram-Negative Bacilli Carriage and Infection in Hospitalized Returning Travelers: A Cross-Sectional Cohort Study. J Travel Med. 2015;22(5):292-9. https://doi. org/10.1111/jtm.12211 PMID: 25997830

41. Heudorf U, Albert-Braun S, Hunfeld K-P, Birne F-U, Schulze J, Strobel K, et al. Multidrug-resistant organisms in refugees: prevalences and impact on infection control in hospitals. GMS Hyg Infect Control. 2016;11:Doc16. PMID: 27579250

42. Piso RJ, Käch R, Pop R, Zillig D, Schibli U, Bassetti S, et al. A Cross-Sectional Study of Colonization Rates with Methicillin-Resistant Staphylococcus aureus (MRSA) and Extended-Spectrum Beta-Lactamase (ESBL) and Carbapenemase-Producing Enterobacteriaceae in Four Swiss Refugee Centres. Huang Y-C, editor. PLOS One. 2017 Jan 13;12(1):e0170251-12.

43. Kaspar T, Schweiger A, Droz S, Marschall J. Colonization with resistant microorganisms in patients transferred from abroad who needs to be screened? Antimicrob Resist Infect Control. 2015;4(31):31. https://doi.org/10.1186/s13756-015-0071-6 PMID: 26213620

44. Nemeth J, Ledergerber B, Preiswerk B, Nobile A, Karrer S, Ruef $C$, et al. Multidrug-resistant bacteria in travellers hospitalized abroad: prevalence, characteristics, and influence on clinical outcome. J Hosp Infect. 2012;82(4):254-9. https://doi. org/10.1016/j.jhin.2012.08.017 PMID: 23103249

45. Birgand G, Armand-Lefevre L, Lepainteur M, Lolom I, Neulier $C$, Reibel F, et al. Introduction of highly resistant bacteria into a hospital via patients repatriated or recently hospitalized in a foreign country. Clin Microbiol Infect. 2014;20(11):0887-90. https://doi.org/10.1111/1469-0691.12604 PMID: 25069719

46. Jaakola S, Lyytikäinen O, Rimhanen-Finne R, Salmenlinna S, Savolainen-Kopra C, Liitsola K, et al. Infectious Diseases in Finland 2016. Helsinki: National Institute for Health and Welfare; 2017. Available from: http://www.julkari.fi/ handle/10024/135619

47. Albiger B, Glasner C, Struelens MJ, Grundmann H, Monnet DLEuropean Survey of Carbapenemase-Producing Enterobacteriaceae (EuSCAPE) working group. Carbapenemaseproducing Enterobacteriaceae in Europe: assessment by national experts from 38 countries, May 2015. Euro Surveill. 2015;20(45):30062. https://doi.org/10.2807/1560-7917. ES.2015.20.45.30062 PMID: 26675038

48. Ravensbergen SJ, Lokate M, Cornish D, Kloeze E, Ott A Friedrich AW, et al. High Prevalence of Infectious Diseases and Drug-Resistant Microorganisms in Asylum Seekers Admitted to Hospital; No Carbapenemase Producing Enterobacteriaceae until September 2015. Cleary PR, editor. PLOS One. 2016 May 4;11(5):e0154791-9.

49. European Centre for Disease Prevention and Control (ECDC). Surveillance of antimicrobial resistance in Europe 2016. Annual Report of the European Antimicrobial Resistance Surveillance Network (EARS-Net). Stockholm: ECDC; 2017 Available from: https://ecdc.europa.eu/en/publications-data/ antimicrobial-resistance-surveillance-europe-2016

50. Heudorf U, Krackhardt B, Karathana M, Kleinkauf N, Zinn C. Multidrug-resistant bacteria in unaccompanied refugee minors arriving in Frankfurt am Main, Germany, October to November 2015. Euro Surveill. 2016;21(2):30109. https://doi. org/10.2807/1560-7917.ES.2016.21.2.30109 PMID: 26838714

51. Hassing RJ, Alsma J, Arcilla MS, van Genderen PJ, Stricker BH, Verbon A. International travel and acquisition of multidrugresistant Enterobacteriaceae: a systematic review. Euro Surveill. 2015;20(47). PMID: 26625301

52. Woerther P-L, Andremont A, Kantele A. Travel-acquired ESBL-producing Enterobacteriaceae: impact of colonization at individual and community level. J Travel Med. $2017 \mathrm{Apr}$ 1;24(suppl_1):S29-S34.

53. Arcilla MS, van Hattem JM, Haverkate MR, Bootsma MCJ van Genderen PJJ, Goorhuis A, et al. Import and spread of extended-spectrum $\beta$-lactamase-producing Enterobacteriaceae by international travellers (COMBAT study): a prospective, multicentre cohort study. Lancet Infect Dis. 2017;17(1):78. 85. https://doi.org/10.1016/S1473-3099(16)30319-X PMID: 27751772

54. Cantón R, González-Alba JM, Galán IC. CTX-M Enzymes: Origin and Diffusion. Front Microbiol. 2012;3:110. https://doi. org/10.3389/fmicb.2012.00110 PMID: 22485109

55. Ranjan A, Shaik S, Hussain A, Nandanwar N, Semmler T, Jadhav S, et al. Genomic and Functional Portrait of a Highly Virulent, CTX-M-15-Producing $\mathrm{H}_{3} 0-\mathrm{Rx}$ Subclone of Escherichia coli Sequence Type 131. Antimicrob Agents Chemother. 2015;59(10):6087-95. https://doi.org/10.1128/AAC.01447-15 PMID: 26195517 
56. McKinnell JA, Miller LG, Eells SJ, Cui E, Huang SS. A systematic literature review and meta-analysis of factors associated with methicillin-resistant Staphylococcus aureus colonization at time of hospital or intensive care unit admission. Infect Control Hosp Epidemiol. 2013;34(10):1077-86. https://doi. org/10.1086/673157 PMID: 24018925

57. Zhou YP, Wilder-Smith A, Hsu LY. The role of international travel in the spread of methicillin-resistant Staphylococcus aureus. J Travel Med. 2014;21(4):272-81. https://doi.org/10.1111/ jtm.12133 PMID: 24894491

58. Stenhem M, Örtqvist A, Ringberg H, Larsson L, Olsson Liljequist B, Haeggman S, et al. Imported methicillinresistant Staphylococcus aureus, Sweden. Emerg Infect Dis. 2010;16(2):189-96. https://doi.org/10.3201/eid1602.081655 PMID: 20113546

59. Siegel JD, Rhinehart E, Jackson M, Chiarello LHealthcare Infection Control Practices Advisory Committee. Management of multidrug-resistant organisms in health care settings, 2006. Am J Infect Control. 2007;35(10) Suppl 2;S165-93. https://doi. org/10.1016/j.ajic.2007.10.006 PMID: 18068814

6o. Eurostat. European statistics. Luxembourg: Eurostat. [Accessed 4 Jan 2017]. Available from: http://ec.europa.eu/eurostat/data/ database

\section{License and copyright}

This is an open-access article distributed under the terms of the Creative Commons Attribution (CC BY 4.0) Licence. You may share and adapt the material, but must give appropriate credit to the source, provide a link to the licence, and indicate if changes were made.

This article is copyright of the authors or their affiliated institutions, 2018. 